\title{
Effects of low-level laser therapy on wound healing
}

\section{Efeitos da laserterapia de baixa potência na cicatrização de feridas cutâneas}

\author{
Fabiana do Socorro da Silva Dias Andrade ${ }^{1}$; Rosana Maria de Oliveira Clark ${ }^{2}$; Manoel Luiz Ferreira ${ }^{2}$
}

A B S T R A C T

\begin{abstract}
Objective: To gather and clarify the actual effects of low-level laser therapy on wound healing and its most effective ways of application in human and veterinary medicine. Methods: We searched original articles published in journals between the years 2000 and 2011, in Spanish, English, French and Portuguese languages, belonging to the following databases: Lilacs, Medline, PubMed and Bireme; Tey should contain the methodological description of the experimental design and parameters used. Results: doses ranging from 3 to $6 \mathrm{~J} / \mathrm{cm}^{2}$ appear to be more effective and doses 10 above $\mathrm{J} / \mathrm{cm}^{2}$ are associated with deleterious effects. The wavelengths ranging from 632.8 to $1000 \mathrm{~nm}$ remain as those that provide more satisfactory results in the wound healing process. Conclusion: Low-level laser can be safely applied to accelerate the resolution of cutaneous wounds, although this fact is closely related to the election of parameters such as dose, time of exposure and wavelength.
\end{abstract}

Key words: Skin. Wound healing. Anti-inflammatory agents. Laser therapy, low-level.

\section{INTRODUCTION}

$\mathrm{T}^{\mathrm{T}}$ he incorporation of laser as a therapeutic tool has been accompanied in the biomedical field since 1960 by Theodore Maiman. One of the first published experiments on the effects of low-level laser dates from 1983, with HeNe (Helium Neon) laser irradiation of wounds in rats for 14 consecutive days ${ }^{1}$.

The effects of low-level laser can be observed in the behavior of lymphocytes, increasing their proliferation and activation; on macrophages, increasing phagocytosis; and on fibroblasts, increasing the secretion of growth factors and enhancing the uptake of both fibrin as collagen. In addition, it contributes to increase the motility of epithelial cells, the amount of granulation tissue and may reduce the synthesis of inflammatory mediators ${ }^{2-5}$. Its action can be observed on the reduction of the area of skin wounds in humans and animals, although the adoption of physical variables involved in the treatments is still not a consensus among authors ${ }^{6-9}$.

Regarding the irradiation protocol, the use of lasers may differ in the type of activation means, the power and dose, and also on the manner and time of irradiation and number of applications ${ }^{3}$.

From the above, and with the growing interest in alternatives to conventional drug therapies, the objective of this was to gather and clarify the actual effects of low-level laser therapy on wound healing and its most effective ways of application in human and veterinary medicine.

\section{METHODS}

This was a qualitative study from original articles published in journals indexed in the following databases: Lilacs, Medline, PubMed and Bireme. We included all original articles whose publication occurred between the years 1984 and 2011 in Spanish, French, English and Portuguese languages and provided methodology containing the parameters used by the applied laser mode. We excluded the research articles that did not contain the methodology regarding the description of the parameters used in their work.

\section{LITERATURE REVIEW}

The acronym LASER has its origin in the English language, abbreviating "light amplification by stimulated emission of radiation". The word laser is established by usage and defines a source of monochromatic, intense, coherent and collimated light, whose emission of radiation is done by stimulating the external field, with varied and growing applications in industry, engineering, human medicine and more

1. Physiotherapy Course, Metropolitan Union of Education and Culture, Itabuna, Bahia State - BA, Brazil; 2. Veterinary Medicine, State University of Santa Cruz, Ilheus, Bahia State - BA, Brazil. 
recently, veterinary medicine ${ }^{10,11}$. In the latter, the rat has been used to study the different aspects involved in cutaneous healing process, being the elected experimental model due to ease of handling ${ }^{12}$.

Lasers are classified into high and low power. The first is generally applied for the removal, cutting and coagulating of tissues, while the low-power ones are more commonly applied in the processes of tissue repair, such as muscle, joint, nerve, bone and skin injuries ${ }^{6,13,14}$.

The photobiological effects of laser radiation can be conventionally divided into short and long term. The responses in the short term are those in which the effect can be observed in a few seconds or minutes after irradiation. The effects observed in the long term are those that occur hours or even days after the end of irradiation and usually involve new cell biosynthesis, especially in the proliferative phase of inflammation 12,15,16.

A wide variety of lasers that promote wound healing can be found in the literature, including:. HeliumCadmium, Argon, Helium-Neon, Krypton, Gallium Arsenide and Aluminium and $\mathrm{CO}_{2}{ }^{6}$. It is known, however, that the success of low power therapy and its respective effects is dependent on wavelength, power, dose and time of application ${ }^{4-8,11,16-23}$ (Table 1).

\section{DISCUSSION}

The repair process is complex and comprises vascular and cellular alterations, epithelial and fibroblasts proliferation, synthesis and deposition of collagen, elastin and proteoglycan production, revascularization and wound contraction ${ }^{8}$. Noteworthy still are the trophic-regenerative, anti-inflammatory and analgesic effects ${ }^{2,8,24}$. It is also claimed that the low-level laser therapy can lead to increased mitochondrial activity, with a consequent increase of adenosine triphosphate (ATP), vasodilation, protein synthesis, decrease in prostaglandin levels, presence of cellular mitosis, migration and proliferation of keratinocytes and neoangiogenesis ${ }^{18,19,23,25}$.

In this sense, a study with HeNe laser, applied at the rate of $4 \mathrm{~J} / \mathrm{cm}^{2}$ showed better effects in the production of collagen type III. In another, it was observed that doses between 7 and $9 \mathrm{~J} / \mathrm{cm}^{2}$ caused the opposite effect, reducing the production of collagen fibers ${ }^{2,18}$.

It is understood that the increased collagen production occurs through photostimulation mechanisms on which certain frequencies/doses may act, thereby modulating cellular proliferation and increasing the amount of fibroblast growth factors. Another possible explanation for this, according to the authors above, would be the better absorption of such energy by the mitochondria and consequently increased production of ATP and nucleic acid, the result being an increase in collagen production, accelerated epithelial repair and facilitated growth of granulation tissue ${ }^{26}$.

According to Zanotti et al. ${ }^{9}$, excitatory doses (up to $8 \mathrm{~J} / \mathrm{cm}^{2}$ ) are indicated when the goal of the intervention includes the enhancement of the sodium/potassium pump; stimulating production of ATP; restoration of the membrane potential; increased metabolism and cell proliferation.

Laser therapy has been administered with the aim of promoting better resolution of inflammation, reducing pain, preventing the occurrence of edema and preserving tissues and nerves adjacent to the site of injury. Such effects can be achieved via wavelengths between 600 and 1000nm and power from $1 \mathrm{~mW}$ to $5 \mathrm{~W} / \mathrm{cm}^{2}$. The authors also emphasize that very low $\left(2.5 \mathrm{~W} / \mathrm{cm}^{2}\right)$ or very high $(25 \mathrm{~W} /$ $\mathrm{cm}^{2}$ ) power can cause the opposite effect ${ }^{27}$.

In a study treating the inflammatory process present in induced arthritis of the knee joint of rats with anti-inflammatory and low-level laser therapy, beneficial effects have been observed both at a dose of $3 \mathrm{~J} / \mathrm{cm}^{2}$ and $30 \mathrm{~J} / \mathrm{cm}^{2}$, although the latter proved more effective in reducing the painful area over 120 hours after the start of treatment, when associated with lower power and applied for ten minutes ${ }^{19}$. Bashardoust Tajali et al. ${ }^{3}$ reported that the wavelength of $632 \mathrm{~nm}$ improved resolution of fractures, thereby demonstrating that there are many results for the use of this therapy.

Although laser has been successfully applied on the symptoms of various diseases, investigators showed that malignant melanoma cells irradiated by Indium-GalliumAluminum-Arsenic-Phosphorus (InGaAlAsP) laser at 660nm wavelength and dose of $1050 \mathrm{~J} / \mathrm{cm}^{2}$ revealed worsening behavior ${ }^{17}$. Furthermore, the use of laser is contraindicated in cases of localized or irradiated malignant tumor; epilepsy; on the thyroid gland; on pregnant abdomen; high hypersensitivity; and thrombosis of pelvic or deep leg veins $^{28,29}$.

\section{FINAL CONSIDERATIONS}

It is concluded that low-level laser therapy, when applied to skin wounds, is able to promote major physiological effects, such as anti-inflammatory resolution, neoangiogenesis, epithelial and fibroblasts proliferation, collagen synthesis and deposition, revascularization and wound contraction. It is also possible to say that doses of 3$6 \mathrm{~J} / \mathrm{cm}^{2}$ appear to be more effective and doses above $10 \mathrm{~J} /$ $\mathrm{cm}^{2}$ are associated with deleterious effects. The wavelengths between 632.8 and $1000 \mathrm{~nm}$ remain as those having more satisfactory results in the wound healing process. 
Tabela 1 - Breve descrição das propostas de tratamento com laserterapia de baixa potência e seus principais resultados.

\begin{tabular}{ll}
\hline Authors & Treatment \\
\hline Busnardo, Simões, 20108 & $\begin{array}{l}\text { HeNe with power } 4 \mathrm{~J} / \mathrm{cm}^{2} \text { applied for } 12 \text { seconds per wound } \\
\text { site in continuous mode, } 5 \mathrm{~mW} \text {, wavelength of } 632.8 \mathrm{~nm} \text { and } \\
\text { the laser beam area of } 0.015 \mathrm{~cm}^{2} .\end{array}$
\end{tabular}

Silva et al., $2010^{16}$

Frigo et al., $2009^{17}$

Maiya et al., 200918

Inoe et al., $2008^{11}$

Channual et al., $2008^{5}$

Pinto et al., $2007^{4}$

Castano et al., $2007^{19}$

Rocha Júnior et al., $2006^{20}$

Hopkins et al., $2004^{21}$

Envemeka, 200122

Landau, Schattner, $2001^{23}$

Al-watban, Andres, $2001^{6}$
Laser applied in 15 Wistar rats divided into three groups: $\mathrm{G} 1$ (control), G2 $\left(2 \mathrm{~J} / \mathrm{cm}^{2}\right)$ and $\mathrm{G} 3\left(4 \mathrm{~J} / \mathrm{cm}^{2}\right)$, with wavelength of 670 $\mathrm{nm}$ and irradiated for 10 consecutive days on skin lesion.

Application of laser once a day on tumor cells, for three consecutive days, with the following parameters: $632 \mathrm{~nm}, 50$ $\mathrm{mW}, 2 \mathrm{~mm}^{2}$ pointer, irradiation area of $2.5 \mathrm{~W} / \mathrm{cm}^{2}$ and times of 60 and 420 seconds at doses of $150 \mathrm{~J} / \mathrm{cm}^{2}$ (group 1, in vitro) and $1050 \mathrm{~J} / \mathrm{cm}^{2}$ (group 2, in vivo), respectively. The third group was not irradiated (control group).

Application of AIGalnP laser $\left(658 \mathrm{~nm}, 4 \mathrm{~J} / \mathrm{cm}^{2}\right)$ in a localized and scanned manner on human decubitus and venous ulcers.

He-Ne laser on skin wounds in diabetic rats, with a wavelength of $632.8 \mathrm{~nm}$ and doses of $3-9 \mathrm{~J} / \mathrm{cm}^{2}$, five days / week until complete healing.

HeNe laser used in doses of 3 and $6 \mathrm{~J} / \mathrm{cm}^{2}, 45 \mathrm{~W}$ of power and wavelength of $632 \mathrm{~nm}$ and a control group, for surgical wounds of healthy rabbits. The animals were evaluated at 7, 14 and 21 days.

Low power laser with a wavelength of $585 \mathrm{~nm}$ and a dose of $7 \mathrm{~J} / \mathrm{cm}^{2}$ on skin wounds of rats.

First week twice with an interval of 48 hours in the weeks following $1 x /$ week, in a localized manner and without the use of additional medication.

Arthritis in rats treated for five days with $810 \mathrm{~nm}$, power 79 and $790 \mathrm{~mW}$, doses of 3 and $30 \mathrm{~J} / \mathrm{cm}^{2}$ and intensities of 5 and $50 \mathrm{~mW} / \mathrm{cm}^{2}$.

Twelve animals divided into two groups: control and experimental. Wound treated for seven days with GaAs laser, pulsatile dose $3.8 \mathrm{~J} / \mathrm{cm}^{2}$ and power of $15 \mathrm{~mW}$ time for 15 seconds.

Abrasive damage induced in non-dominant upper limb in two groups of healthy people. One group was treated with a dose of $8 \mathrm{~J} / \mathrm{cm}^{2}$, wavelength $820 \mathrm{~nm}$ and two minutes exposure. The other group was treated under the same parameters for five seconds. A third group was not treated.

HeNe laser (632.8 nm, continuous) and GaAs laser (904nm, continuous) in cutaneous lesions of rats.

HeNe laser $\left(632 \mathrm{~nm} / 5 \mathrm{~mW}\right.$ and $\left.904 \mathrm{~nm} / 60 \mathrm{~W} ; 4 \mathrm{~J} / \mathrm{cm}^{2}\right)$ associated with topical hyperbaric oxygen supply for 20 minutes per session on diabetic foot ulcers over 14 weeks.

HeNe $\left(632.8 \mathrm{~nm}\right.$ wavelength, dose of $5 \mathrm{~J} / \mathrm{cm}^{2}$ and power of $10.53 \mathrm{~mW} / \mathrm{cm}^{2}$ ), applied three times per week in in vivo cells until complete healing of the wound.

\section{Resiults}

Increase of type III collagen, decreased inflammatory infiltrate and early resolution of wound inflammatory phase.

The dose of $4 \mathrm{~J} / \mathrm{cm}^{2}$ differed significantly from the others concerning the reepithelialization process.

Between the in vitro and the control group, there was no statistically significant difference in the growth of tumor cells. Comparing group 2 and control, there was significant growth of mass and volume to the tumor, as well as a large number of blood vessels in the in vivo group.

Reduction of the wounds area.

Increased production of granulation tissue in the animals that received doses of 4-5J/ $\mathrm{cm}^{2}$, especially on the fifth day of treatment.

Observed the presence of mature granulation tissue at 14 days and absence of hemorrhage and exudate at day 21 .

Permanent vascular proliferation after the fifth day of application.

The results revealed granulation tissue, reducing inflammation and pain relief from the first application.

Increase of adenosine triphosphate (ATP) and improved inflammatory process.

Tissue repair significantly larger and more organized in the experimental group.

The groups treated with low level laser showed a statistically significant reduction in the wound when compared to the control group at the 6 th, 8 th and 10 th days of treatment.

Improvement of wound healing for both wave lengths adopted, though the latter presented more pronounced findings.

Complete healing of ulcers after 25 sessions and only $4 \%$ of recurrence.

Increased cell proliferation (fibroblasts and mitochondria), as well as microcirculation, with a consequent increase in cellular metabolism. 
Objetivo: reunir e esclarecer quais os reais efeitos da laserterapia de baixa potência sobre feridas cutâneas e suas formas mais eficazes de aplicação na medicina humana e veterinária. Métodos: foram pesquisados artigos originais publicados em periódicos pertencentes às seguintes bases de dados: Lilacs, MedLine, Bireme e PubMed entre os anos de 2000 e 2011, na línguas espanhola, inglesa, francesa e portuguesa, que contivessem a descrição metodológica do modelo experimental e parâmetros utilizados no

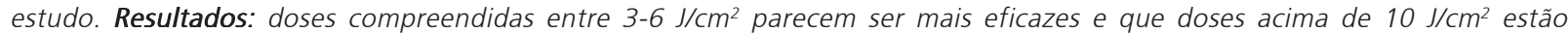
associadas a efeitos deletérios. Os comprimentos de onda compreendidos entre 632,8-1000nm seguem como aqueles que apresentam resultados mais satisfatórios no processo de cicatrização tecidual. Conclusão: o laser de baixa potência pode ser indicado com segurança para acelerar a resolução de feridas cutâneas, muito embora este fato esteja intimamente ligado à eleição de parâmetros como dose, tempo e comprimento de onda.

Descritores: Pele. Cicatrização de feridas. Anti-inflamatórios. Terapia a laser de baixa intensidade.

\section{REFERENCES}

1. Henriques ACG, Cazal C, Castro JFL. Ação da laserterapia no processo de proliferação celular: revisão de literatura. Rev Col Bras Cir. 2010;37(4):295-302.

2. Bourguignon Filho AM, Feitosa ACF, Beltrão GC, Pagnoncelli GC. Utilização do laser de baixa intensidade no processo de cicatrização tecidual. Revisão de literatura. Rev Port Estomatol Cir Maxilofac. 2005;46(1);37-43.

3. Bashardoust Tajali S, Macdermid JC, Houghton P, Grewal R. Effects of low power laser irradiation on bone healing in animals: a metaanalysis. J Orthop Surg Res. 2010;5:1-13.

4. Pinto NC, Pereira, HC, Stolf NAG, Chavantes MC. Laser de baixa intensidade em deiscência aguda safenectomia: proposta terapêutica. Rev Bras Cir Cardiovasc. 2009;24(1);88-91.

5. Channual J, Choi B, Osann K, Pattanachinda D, Lotfi J, Kelly KM. Vascular effects of photodynamic and pulsed dye laser therapy protocols. Lasers Surg Med. 2008;40(9);644-50.

6. Al-watban FAH, Andres BL. Laser photons and pharmacological treatments in wound healing. Laser Therapy. 2001;12:1-9.

7. Felice TD, Pinheiro AR, Menchik EDS, Silva ACD, Souza LS, Caires CSA, et al. Utilização do laser de baixa potência na cicatrização de feridas. Interbio. 2009;3(2);42-52.

8. Busnardo VL, Biondo-Simões MLP. Os efeitos do laser hélio-neônio de baixa intensidade na cicatrização de lesões cutâneas induzidas em ratos. Rev bras fisioter. 2010;14(1):45-51.

9. Zanotti GB, Oliveira PI, Reis SFS, Silva FS, Araújo AR. Efeitos do laser de baixa potência sobre a regeneração da cartilagem na osteoartrose. Rev fisio bras. 2011;12(2):139-46.

10. Salcido R, Adrian P, Chulhyun A. Animal models in pressure ulcer research. J Spinal Cord Med. 2007;30(2):107-16.

11. Inoe AP, Zafanelli CCG, Rossato RM, Leme MC, Sanches AWD, Araújo CV, et al. Avaliação morfológica do efeito do laser de baixa potência He-Ne em feridas cutâneas de coelhos. Arq ciênc vet zool Unipar. 2008;11(1):27-30

12. Abergel RP, Lam TS, Dwyer RM, Lesavoy MA, Uitto J. Control of connective tissue metabolism by lasers: recent developments and future prospects. J Am Acad Dermatol. 1984;11(6):142-50.

13. Barreto JG, Salgado CG. Clinic-epidemiological evaluation of ulcers in patients with leprosy sequelae and the effect of low-level laser therapy on wound healing: a randomized clinical trial. BMC Infect Dis. 2010;10:237-45.

14. Lacerda MS, Nunes TC. Efeitos do cetoprofeno e flunixin meglumine namodulação neuroendócrina à dor pós-operatória em cadelas submetidas a ovário-histerectomia. Biosci J. 2008;24(4):131-7.

15. Dogan SK, Saime AY, Evcki D. The effectiveness of low-level laser therapy in subacromial impingement syndrome: a randomized placebo controlled double-blind prospective study. Clinics. 2010;65(10):1019-22.
16. Silva TS, Mendes F, Alves AMP, Alves EPB, Bertolini GRF. Estudo microscópio da lesão tecidual em pele de ratos Wistar tratados com laser de baixa potência. Rev Bras Bioci. 2010;8(3);264-7.

17. Frigo L, Luppi JSS, Favero GM, Maria DA, Penna SC, Bjordal JM, et al. The effect of low-level laser irradiation (In-Ga-Al-AsP - 660 $\mathrm{nm}$ ) on melanoma in vitro and in vivo. BMC Cancer. 2009;9:40411.

18. Maiya AG, Kumar P, Nayak S. Photo-stimulatory effect of low energy helium-neon laser irradiation on excisional diabetic wound healing dynamics in wistar rats. Indian J Dermatol. 2009;54(4):3239.

19. Castano AP, Dai T, Yaroslavsky I, Cohen R, Apruzzese WA, Smotrich $\mathrm{MH}$, et al. Low-level laser therapy for zymosan-induced arthritis in rats: importance of illumination time. Lasers Surg Med. 2007;39(6):543-50.

20. Rocha Júnior AM, Oliveira RG, Farias RE, Andrade LCF. Aarestrup FM. Modulação da proliferação fibroblástica e da resposta inflamatória pela terapia a laser de baixa intensidade no processo de reparo tecidual. An Bras Dermatol. 2006;81(2):150-6.

21. Hopkins JT, McLoda TA, Seegmiller JG, Baxter GD. Low-level laser therapy facilitates superficial wound healing in humans: a tripleblind, sham-controlled study. J Athl Train. 2004;39(3):223-9.

22. Envemeka CS. Attenuation and penetration of visible $632.8 \mathrm{~nm}$ and invisible infra-red $904 \mathrm{~nm}$ light in soft tissues. Laser Therapy. 2001;13:95-101.

23. Landau Z, Schattner A. Topical hyperbaric oxygen and low energy laser therapy for chronic diabetic foot ulcers resistant to conventional treatment. Yale J Biol Med. 2001;74(2): 95-100.

24. Verhey JF, Mohammed Y, Ludwig A, Giese K. Implementation of a practical model for light and heat distribution using laser-induced thermotherapy near to a large vessel. Phys Med Biol. 2003;48(21):3595-610.

25. Izikson L, Nelson JS, Anderson RR. Treatment of hypertrophic and resistant port wine stains with a $755 \mathrm{~nm}$ laser: a case series of 20 patients. Lasers Sur Med. 2009;41(6):427-32.

26. Giuliani A, Lorenzini L, Gallamini M, Massella A, Giardino L, Calzà L. Low infra red laser light irradiation on cultured neural cells: effects on mitochondria and cell viability. BMC Complement Altern Med. 2009:9:8.

27. Huang YY, Chen AC, Carroll JD, Hamblin MR. Biphasic dose response in low level light therapy. Dose Response. 2009;7(4): 358-83.

28. Moshkovska T, Mayberry J. It is time to test low level laser therapy in Great Britain. Postgrad Med J. 2005;81(957):436-41.

29. Bjordal JM, Lopes-Martins RA, Joensen J, Couppe C, Ljunggren $A E$, Stergioulas $A$, et al. A systematic review with procedural assessments and meta-analysis of low-level laser therapy in lateral elbow tendinopathy (tennis elbow). BMC Musculoskelet Disord. 2008;29;9:75. 
Received on 10/10/2012

Accepted for publication 15/12/2012

Conflict of interest: none.

Source of funding: none.

How to cite this article:

Andrade FSSD, Clark RMO, Ferreira ML. Effects of low-level laser

therapy on wound healing. Rev Col Bras Cir. [periódico na Internet]

2014;41(2). Disponível em URL: http://www.scielo.br/rcbc
Address for correspondence:

Fabiana do Socorro da Silva Dias Andrade

E-mail: fabi4000@gmail.com 